\title{
TERPAAN PESAN IKLAN ANTI KEKERASAN RADIO PRAMBORS DAN INTERAKSI PEER GROUP TERHADAP SIKAP ANTI KEKERASAN REMAJA
}

\section{THE EXPOSURE OF ANTI VIOLENCE ADVERTISING MESSAGE IN PRAMBORS RADIO AND PEER GROUP INTERACTION TOWARD ANTI VIOLENCE ATTITUDE ON TEENAGER}

\author{
Ayang Fitrianti \\ (ayangfitrianti@gmail.com) \\ (Magister Ilmu Komunikasi, FISIP, UNDIP)
}

\begin{abstract}
Abstrak
Karateristik remaja yang ekspresif, selalu ingin tahu dan mudah menerima nilai-nilai baru pada era globalisasi ini harus diarahkan dan dikawal pada hal-hal yang positif seperti yang dilakukan oleh Radio Prambors dengan menayangkan Pesan Iklan Anti Kekerasan. Oleh karena itu penelitian ini bertujuan untuk mengetahui sejauh mana Terpaan Pesan Iklan Anti Kekerasan Radio Prambors dan Peer Group terhadap Sikap Anti Kekerasan Remaja. Metode yang digunakan pada penelitian ini adalah metode kuantitatif secara eksplanatif dengan paradigma positivistik. Teori yang digunakan pada penelitian ini adalah teori Belajar Sosial Bandura dan teori Hierarchy Effect Model. Penelitian ini menggunakan metode survey dengan responden sebanyak 116 orang responden yang merupakan pendengar Radio Prambors. Berdasarkan penelitian yang telah dilakukan dapat disimpulkan bahwa Terpaan Pesan Iklan Anti Kekerasan memiliki hubungan positif terhadap Sikap Anti Kekerasan Remaja. Selain itu hasil penelitian juga menunjukkan bahwa Interaksi dengan Peer Group juga menunjukan hubungan positif yang signifikan terhadap Sikap Anti Kekerasan Remaja.

Kata Kunci: Iklan, Radio Prambors, Remaja
\end{abstract}

\begin{abstract}
Characteristic teen expressive, always curious and receptive to new values in this era of globalization should be directed and escorted on positive things like Prambors Radio which serve Ad Links anti Violence. Therefore, this study aims to determine the extent of Exposure to Violence Ad Links Prambors Radio and Peer Group of the Attitudes of Teen Violence. The method used in this research is quantitative method, explanatory paradigm of positivistic. The theory used in this study is the Social Learning Theory by Bandura and the theory of Hierarchy Effect Model. This study uses survey respondents were 116 respondents who are listeners Prambors Radio. Based on this research, it can be concluded that the inundation Ad Links Anti Violence positively related to Attitude Teen Violence. In addition the results also showed that interaction with the Peer Group also showed a significant positive correlation to the attitude of Teen Violence.
\end{abstract}

Keywords: Ad, Prambors Radio, Teenager

\section{Pendahuluan}

Kasus kekerasan remaja seperti; perkelahian antar pelajar, tawuran, kebrutalan geng motor sekarang makin ditemui di beberapa kota besar di Indonesia. Tidak sedikit diantaranya bahkan mengakibatkan timbulnya korban jiwa. Kasus-kasus semacam ini tentunya menjadi perhatian dan keprihatinan banyak pihak dan mendesak untuk dicari penyelesaian yang komprehensif agar tidak

kembali terulang di kemudian hari. Besarnya penduduk remaja di Indonesia tentunya akan berperan besar bagi kemajuan bangsa. Karakteristik remaja yang selalu ekspresif, selalu ingin tahu dan mudah menerima nilai-nilai baru merupakan hal yang harus terus dikawal dan diarahkan pada hal-hal yang positif.

Untuk mengatasi kekerasan remaja perlu diupayakan sosialisasi supaya para 
remaja membiasakan diri untuk melakukan interaksi yang berupa kompetisi, karena merupakan sarana seleksi untuk mengetahui generasi muda yang berkualitas. Perlu adanya sosialisasi bahwa konflik tidak bisa diselesaikan dengan jalan kekerasan, sehinggakonflik tidak akan menimbulkan kekerasan dan bahwa menghentikan kekerasan dengan jalan kekerasan tidak akan membawa hasil pada perdamaian yang efektif, namun justru menciptakan lingkaran setan tiada akhir (Efianingrum, 2006).

Dalam sebuah komunikasi massa, peran media massa sangat penting, yaitu melalui media massa modern seperti surat kabar, televisi, radio bahkan film. Komunikasi massa ialah penyebaran pesan dengan menggunakan media yang ditujukkan kepada massa abstrak, yakni sejumlah orang yang tidak tampak oleh si penyampai pesan (Effendy, 2002). Media massa memiliki kekuatan strategis dalam menyebarkan informasi,sehingga memiliki pengaruh dalam membentuk sikap dan norma sosial suatu masyarakat. Media massa juga bisa menampilkan teladan budaya yang bijak untuk mengubah masyarakat, sehingga masyarakat dapat dipengaruhi oleh terpaan media massa (Reza et al., 2012).

Namun demikian sebagian ahli berpendapat bahwa terpaan media bukan satu-satunya faktor yang mempengaruhi sikap seseorang. John Klaper (dalam Sundari, 2014) berpendapat bahwa faktor psikologis dan sosial ikut mempengaruhi dalam proses penerimaan pesan dari media massa. Faktor-faktor tersebut antara lain, proses seleksi, proses kelompok, norma kelompok dan keberadaan pemimpin opini. Hal yang sama juga disimpulkan oleh Sander dan Pace (dalam Sundari, 2014) bahwa media massa pada dasarnya hanya mampu berada pada tataran pembentukan citra (image), sementara yang berperan untuk mengajak orang untuk mengubah pilihan adalah komunikasi antar pribadi.
Oleh karena itu, perlu diteliti lebih lanjut hubungan kedua faktor; terpaan media (yang dalam hal ini adalah terpaan pesan iklan anti kekerasan dalam Radio Prambors) dan interaksi peer group dengan sikap anti kekerasan remaja.

Dengan mendasarkan pada latar belakang di atasmaka permasalahan yang diajukan dalam penelitian ini adalah 'Apakah Terpaan Pesan Iklan Anti Kekerasan Radio Prambors dan Interaksi dengan Peer Group berhubungan dengan Sikap Anti Kekerasan Remaja?'

Penelitian ini bertujuan untuk mengetahui hubungan antara Terpaan Pesan Iklan Anti kekerasan Radio Prambors dan interaksi dengan Peer Group dengan Sikap Anti Kekerasan Remaja

Untuk pendekatan yang diambil dalam penelitian ini adalah teori belajar Bandura dan hierarchy of effects. Tentunya berbeda dengan penelitian terdahulu yang menggunakan pendekatan teori yang sama, penelitian ini bukan bertujuan mengukur tingkat efektifitas media iklan yang digunakan perusahaan melainkan melihat apakah remaja yang terterpa pesan yang diberikan radio dengan bagaimana sikap mereka.

Teori pembelajaran sosial ini adalah perkembangan utama dari tradisi teori pembelajaran perilaku (Behaviorisme). Berbeda dengan penganut Behaviorisme, Teori Bandura menjelaskan perilaku manusia dalam konteks interaksi timbal balik yang berkesinambungan antara kognitif, perilaku dan pengaruh lingkungan. Kondisi lingkungan sekitar individu sangat berpengaruh pada pola belajar sosial ini.

Prinsip dasar belajar menurut teori ini, bahwa yang dipelajari individu terutama dalam belajar sosial dan moral terjadi melalui peniruan (imitation) dan penyajian contoh perilaku (modeling). Teori ini juga masih memandang pentingnya conditioning. Melalui pemberian reward dan punishment, 
seorang individu akan berfikir dan memutuskan perilaku sosial mana yang perlu dilakukan.

Hierachy of Effects dari Lavidge dan Steiner sebenarnya merupakan salah satu model perilaku konsumen namun teori ini menyediakan sudut pandang umum untuk menganalisa dampak komunikasi termasuk di dalamnya respon maupun sikap terhadap pesan (Belch \& Belch, 2004). Dalam Hierachy of Effects diperlihatkan prosesbagaimana sebuah program kehumasan bekerja dan mengharuskan publiknya melewati serangkaian tahapan mental mulai dari sadar akan keberadaan program tersebut hingga organisasi yang menyelenggarakan program tersebut.

Terpaan dapat diartikan di sini adalah bahwa suatu keadaan dimana khalayak atau pembaca terkena pesan komunikasi yang terdapat pada suatu media massa melalui alat inderanya seperti perasaan, pendengaran dan penglihatan. Terpaan ditentukan dari frekuensi, intensitas dan durasi suatu media dilihat atau dibaca. Sesering dan selama apapun seseorang melihat suatu media, belum tentu ia melihat media tersebut secara seksama (dari awal sampai akhir), bisa saja hanya sekilas atau sebagian (Wells et al, 2000). Namun demikian komunikasi massa menimbulkan efek pada diri khalayaknya (Rakhmat, 2004). Lavidge \& Steiner menyatakan bahwa terdapat beberapa tahapan sikap pada konsumen setelah terkena iklan suatu produk sampai pada saat ia memutuskan untuk membeli produk tersebut. Sikap pada konsumen dibagi menjadi tiga jenis dasar proses psikologi yaitu: kognitif, afektif dan konatif (Horton, 1984).

Interaksi komunikasi kelompok Peer Groupatau teman sebaya adalah komunikasi yang dilakukan secara dua arah dalam kelompok yang anggotanya berada dalam satu tingkatan atau range usia yang sama. Komunikasi kelompok teman sebaya akan berjalan dengan baik jika interaksi komunikasi yang dilakukan intensitasnya cukup sering dilakukan. Interaksi komunikasi dapat mempengaruhi perilaku remaja dilihat dari frekuensi, isi pesan dan durasi dalam setiap interaksi yang dilakukan remaja.

Menurut Santrock (2007) orang dengan tingkat umur dan kedewasaan yang kira-kira sama bisa berfungsi sebagai sumber informasi dan perbandingan tentang dunia luar selain keluarga. Pada saat remaja individu umumnya bergabung dengan kelompok teman sebaya. Hurlock (2004) menyatakan bahwa remaja memiliki kecenderungan untuk membentuk kelompok dan melakukan interaksi bersama teman-temannya dalam usahanya melepaskan diri dari ketergantungannya pada orang tua atau keluarganya.

Berdasarkan kerangka konsep hubungan antara terpaan pesan iklan iklan dan interaksi peer group dengan sikap anti kekerasan maka hipotesis yang diajukan dalam penelitian ini adalah:

1. $H_{1}$ : Terdapat hubungan antara terpaan Pesan Iklan Anti kekerasan dengan Sikap Anti Kekerasan Remaja;

2. $\mathrm{H}_{2}$ : Terdapat hubungan antara Interaksi Peer Group dengan Sikap Anti Kekerasan Remaja.

\section{Metodologi}

Penelitian ini menggunakan pendekatan penilitian eksplanatori dan deskriptif. Penelitian eksplanatori adalah penelitian yang berusaha mencari pengaruh variabel tertentu terhadap variabel yang lain. bahwa penelitian eksplanatory adalah penelitian yang bertujuan menelaah kausalitas antar variabel yang menjelaskan suatu fenomena tertentu.

Populasi adalah wilayah generalisasi yang terdiri atas: obyek/subyek yang mempunyai kualitas dan karakteistik tertentu yang ditetapkan oleh peneliti untuk dipelajari dan kemudian ditarik kesimpulannya (Sugiyono, 2012). Populasi dalam penelitian ini adalah 
remaja pendengar setia radio Prambors yang berdomisili di kota Semarang. Teknik sampling yang digunakan dalam penelitian ini adalah sistematic random sampling. Teknik pengambilan sampel ini digunakan mengingat jumlah populasi sudah diketahui yaitu 1025 orang. Sistematic random sampling adalah teknik penentuan sampel dengan cara acak sistmatis. Teknik ini dilakukan cara mengambil sampel pertama secara acak kemudian sampel selanjutnya diambil secara sistematis nomor urut kelipatan 5 (dari nomor urut sampel pertama).

Untuk menentukan nilai atas persepsi responden dibentuk sebuah kuesioner. Setiap responden diminta pendapatnya mengenai suatu pertanyaan atau pernyataan. Skala pengukuran memakai skala interval. Jawaban diberi penilaian dari 1 sampai 7 .

Metode analisis data yang digunakan dalam penelitian ini adalah dengan menggunakan metode kuantitatif yaitu penafsiran data yang bersifat kuantitatif dengan menggunakan analisis secara matematis. Dalam metode kuantitatif ini alat analisis yang digunakan adalah dengan menggunakan model crosssection, yang memiliki observasi pada suatu analisis pada satu waktu tertentu.

Dalam penelitian ini analisis data dilakukan sesuai dengan tujuan penelitian. Agar dapat mengambil kesimpulan berdasarkan hasil regresi maka model persamaan harus terbebas dari asumsi klasik. Dari hasil tersebut maka persamaan regresi berganda adalah sebagai berikut:

Sikap Anti Kekerasan $=0,462$ Terpaan Iklan + 0,489 Peer Group + e,

Dari persamaan yang diperoleh, dapat diketahui bahwa secara berturutturut variabel yang paling berpengaruh terhadap sikap anti kekerasan adalah variabel peer group dengan koefisien regresi sebesar 0.489 selanjutnya variabel terpaan iklan dengan koefisien regresi 0.462 .
1. hubungan terpaan iklan terhadap sikap anti kekerasan $\mathrm{t}$ hitung variabel terpaan iklan adalah sebesar 0,489 dengan signifikansi $0.000<0.05$ berarti variabel terpaan iklan berpengaruh positif signifikan terhadap sikap anti kekerasan. Dengan demikian Hipotesis Satu yang berbunyi terdapat hubungan positif antara terpaan pesan iklan anti kekerasan dengan sikap anti kekerasan remaja diterima.

2. hubungan peer group terhadap sikap anti kekerasan $t$ hitung variabel peer group adalah sebesar 0,462 dengan signifikansi $0.000<0.05$ berarti variabel peer group berpengaruh positif signifikan terhadap sikap anti kekerasan. Dengan demikian Hipotesis Dua yang berbunyi terdapat hubungan positif antara peer group dengan sikap anti kekerasan remaja diterima.

Pengujian secara simultan dilakukan dengan menggunakan uji $\mathrm{F}$ (uji ANOVA) yang berguna untuk menguji pengaruh secara bersama-sama variabel-variabel bebas terhadap variabel terikatnya. Pengujian ini dilakukan dengan cara membandingkan nilai $\mathrm{F}$ hitung dengan nilai $\mathrm{F}$ tabel tingkat signifikansi $(\alpha) 5 \%$.

Terpaan iklan dan peer group secara simultan memiliki hubungan yang signifikan terhadap sikap anti kekerasan.

Artinya bahwa variabel terpaan pesan iklan dan interaksi peer group berubah $49,4 \%$ terhadap variabel sikap anti kekerasan, sedangkan sisanya sebesar $50,6 \%$ berhubungan dengan variabel lain yang tidak dimasukkan dalam penelitian.

\section{Hasil dan Pembahasan}

Penelitian telah dilakukan pada 116 responden yang didapatkan dari pendengar setia Radio Prambors Semarang. Sampel diambil secara acak. Instrumen yang digunakan untuk memperoleh data berupa kuesioner tertutup. Skala yang digunakan pada kuesioner penelitian ini adalah skala likert dengan rentang antara 1 (satu) sampai 7 (tujuh). Kuesioner penelitian 
berisi 24 item pernyataan. Angka 1 (satu) pada kuesioner penelitian menunjukan 'sangat tidak setuju' terhadap pernyataan, sedangkan angka 7 (tujuh) menunjukan 'sangat setuju' terhadap pernyataan. Berikut ini pembagiannya:

\begin{tabular}{|c|c|}
\hline Skor & Kategori \\
\hline 1 & Sangat Tidak Setuju \\
\hline 2 & Tidak Setuju \\
\hline 3 & Agak Tidak Setuju \\
\hline 4 & Agak Sedikit Setuju \\
\hline 5 & Agak Setuju \\
\hline 6 & Setuju \\
\hline 7 & Sangat Setuju \\
\hline
\end{tabular}

Tabel 1. Skala Likert

Variabel $1 \quad\left(\mathrm{X}_{1}\right)$ merupakan pernyataan nomor 1 sampai 7 yang mewakili 'Terpaan Pesan Iklan'. Variable $2\left(\mathrm{X}_{2}\right)$ merupakan pernyataan nomor 8 sampai 15 yang mewakili 'Interaksi Peer Group'. Variable 3 yang merupakan variabel $\mathrm{Y}$ atau variabel independen dalam penelitian ini meliputi pernyataan nomor 16 sampai 24 yang mewakili 'Sikap Terhadap Anti Kekerasan'.

\begin{tabular}{|c|c|c|c|}
\hline No & $\begin{array}{c}\text { Jenis } \\
\text { Kelamin }\end{array}$ & Jumlah & Persentase \\
\hline 1 & Pria & 73 & 63 \\
2 & Wanita & 43 & 37 \\
\hline \multicolumn{2}{|c|}{ Jumlah } & 116 & 100 \\
\hline
\end{tabular}

Tabel 2. Jenis Kelamin

\begin{tabular}{|c|c|c|c|}
\hline No & Usia & Jumlah & Persentase \\
\hline 1. & $<20$ tahun & 69 & 59 \\
2. & $21-30$ tahun & 39 & 34 \\
3. & $>30$ tahun & 8 & 7 \\
\hline \multicolumn{2}{|c|}{ Jumlah } & 116 & 100 \\
\hline
\end{tabular}

Tabel 3. Usia Responden

(Sumber: data primer yang diolah, 2016)

Dalam penelitian ini analisis data dilakukan sesuai dengan tujuan penelitian. Agar dapat mengambil kesimpulan berdasarkan hasil regresi maka model persamaan harus terbebas dari asumsi klasik.

Berdasarkan hasil tersebut maka persamaan regresi berganda adalah sebagai berikut:
Sikap Anti Kekerasan $=0,462$ Terpaan Iklan + 0,489 Peer Group + e, Hasil olah data SPSS ditunjukkan dalam tabel berikut:

\begin{tabular}{|c|l|l|l|l|l|}
\hline Model & $\begin{array}{c}\text { Sum } \\
\text { of } \\
\text { Squ- } \\
\text { ares }\end{array}$ & df & $\begin{array}{c}\text { Mean } \\
\text { Square }\end{array}$ & F & $\begin{array}{l}\text { Sig } \\
\cdot\end{array}$ \\
\hline $\begin{array}{l}\text { Regre- } \\
\text { ssion }\end{array}$ & 1425.8 & 2 & 712.90 & 55. & .00 \\
& 6 & 209 & $0^{\mathrm{b}}$ \\
1 & $\begin{array}{l}\text { Resi- } \\
\text { dual }\end{array}$ & $\begin{array}{l}1459.1 \\
54\end{array}$ & 11 & 12.913 & \\
\\
Total & $\begin{array}{l}2884.9 \\
66\end{array}$ & 11 & 5 & & \\
\hline
\end{tabular}

Tabel 4. ANOVA ${ }^{\mathrm{a}}$

a. Dependent Variable: Sikap Anti Kekerasan

b. Predictors: (Constant), Terpaan Iklan, Peer Group

Dari persamaan yang diperoleh, dapat diketahui bahwa secara berturut variabel yang paling berpengaruh terhadap sikap anti kekerasan adalah variabel peer group dengan koefisien regresi sebesar 0.489 selanjutnya variabel terpaan iklan dengan koefisien regresi 0.462 .

Tabel menunjukkan bahwa terpaan iklan dan peer group secara simultan memiliki hubungan yang signifikan terhadap sikap anti kekerasan.

Hasil uji koefisien determinasi

Model Summary

\begin{tabular}{|l|l|l|l|l|}
\hline $\begin{array}{l}\text { Mo } \\
\text { del }\end{array}$ & R & $\begin{array}{l}\text { R } \\
\text { Squar } \\
\text { e }\end{array}$ & $\begin{array}{l}\text { Adjusted } \\
\text { R Square }\end{array}$ & $\begin{array}{l}\text { Std. } \\
\text { Error of } \\
\text { the } \\
\text { Estimate }\end{array}$ \\
\hline 1 & $.703^{\mathrm{a}}$ & .494 & .485 & 3.593 \\
\hline
\end{tabular}

Tabel 5. Tabel Adjusted $r$ Square

a. Predictors: (Constant), Terpaan Iklan, Peer Group

Tabel di atas menunjukkan bahwa besarnya nilai $\mathrm{R}$ square adalah 0.494 artinya bahwa variabel terpaan pesan iklan dan interaksi peer group berubah $49,4 \%$ terhadap variabel sikap anti kekerasan, 
sedangkan sisanya sebesar 50,6\% berhubungan dengan variabel lain yang tidak dimasukkan dalam penelitian.

Dengan demikian dapat disimpulkan bahwa terpaan iklan memiliki hubungan positif terhadap sikap anti kekerasan. Hubungan positif ini dapat dilihat dari besarnya kecenderungan untuk menolak setiap bentuk kekerasan dan pandangan tentang kekerasan sebagai solusi permasalahan.

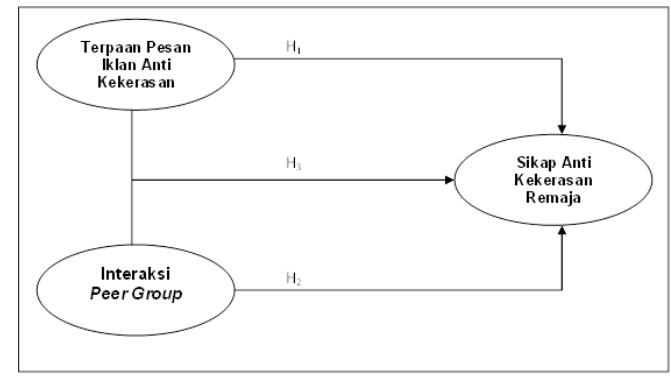

Gambar 1. Kerangka

Disamping itu hasil penelitian juga menunjukkan bahwa interaksi dengan peer group memiliki hubungan positif yang signifikan terhadap anti kekerasan remaja. Hal ini ditunjukkan dengan sikap remaja yang meskipun sering menunjukkan persetujuan terhadap pendapat temannya tetapi dalam hal kekerasan mereka cenderung menolak.

Dalam penelitian kali ini teori yang digunakan adalah Teori Belajar Sosial Bandura (Observational Learning Theory) dan Teori Hierarchy of Effects dari Lavidge dan Steiner. Hasil olah data menunjukkan bahwa terpaan iklan memiliki hubungan yang signifikan terhadap sikap anti kekerasan remaja. Ini berarti bahwa semakin tinggi terpaan iklan maka sikap anti kekerasan remaja akan meningkat. Dengan demikian ini mendukung pendapat dari Lavidge \& Steiner (dalam Horton, 1984) yang menyatakan bahwa terdapat beberapa tahapan sikap pada konsumen setelah terkena iklan suatu produk sampai pada saat ia memutuskan untuk membeli produk tersebut. Sikap pada konsumen dibagi menjadi tiga jenis dasar proses psikologi yaitu: kognitif, afektif dan konatif (Horton, 1984). Kognitif meliputi peningkatan kesadaran, belajar, dan tambahan pengetahuan. Efek afektif berhubungan dengan emosi, perasaan dan sikap, sedangkan konatif berhubungan dengan perilaku dan niat untuk melakukan sesuatu menurut cara tertentu.

Hasil olah data juga menunjukkan bahwa peer gorup memiliki hubungan yang signifikan terhadap sikap anti kekerasan remaja. Ini berarti bahwa semakin tinggi interaksi dengan peer group maka sikap anti kekerasan remaja akan meningkat. Dengan demikian hal ini mendukung hasil penelitian sesuai dengan Social Learning Theory (Teori Belajar Sosial) dari Bandura yang menyatakan bahwa orang belajar dari yang lain, melalui observasi, peniruan, dan pemodelan. Menurut Bandura, setiap proses belajar terjadi dalam urutan tahapan peristiwa (4 unsur utama) dan berakhir dengan penampilan atau kinerja (performance) tertentu sebagai hasil/ perolehan belajar seorang siswa. yang meliputi:

\section{- $\quad$ Fase Perhatian (Attentian)}

Memberikan perhatian pada orang yang ditiru. Sebagai pengamat orang tidak dapat belajar melalui observasi kecuali kaku ia memperhatikan kegiatan-kegiatan yang diperagakan oleh model itu sendiri dan benar-benar memahaminya. Mencakup peristiwa peniruan (adanya kejelasan, keterlibatan perasaan, tingkat kerumitan, kelaziman, nilai fungsi) dan karakteristik pengamatan (kemampuan indera, minat, persepsi, penguatan sebelumnya).

- $\quad$ Fase Pengingat (Retention)

Seorang pengamat harus dapat mengingat apa yang yang telah dilihatnya. Dia harus mengubah informasi yang diamatinya menjadi bentuk gambaran mental, atau mengubah simbol-simbol verbal, dan kemudian menyimpan dalam ingatannya. Mencakup kode pengkodean simbolik, pengorganisasian pikiran, pengulangan simbol, pengulangan motorik.

- $\quad$ Reproduksi Motorik (Reproduction) 
Yaitu proses peniruan adalah mengubah ide gambaran, atau ingatan menjadi tindakan. Mencakup kemampuan fisik, kemampuan meniru, keakuratan umpan balik.

- Peneguhan/Motivasi

(Reinforcement/Motivation)

Mencakup dorongan dari luar dan penghargaan terhadap diri sendiri.

Adapun prinsip-prinsip yang mendasari teori belajar sosial yang dikemukakan oleh Bandura, yaitu:

1) Prinsip faktor-faktor yang saling menentukan.

Bandura menyatakan bahwa diri seorang manusia pada dasarnya adalah suatu sistem (sistem diri/self system). Sebagai suatu sistem bermakna bahwa perilaku, berbagai faktor pada diri seseorang, dan peristiwaperistiwa yang terjadi dalam lingkungan orang tersebut, secara bersama-sama saling bertindak sebagai penentu atau penyebab yang satu terhadap yang lainnya. Berikut ini dijelaskan interaksi berbagai faktor pembentuk sistem diri (self sistem) pada sebuah bagan (Gambar 2)

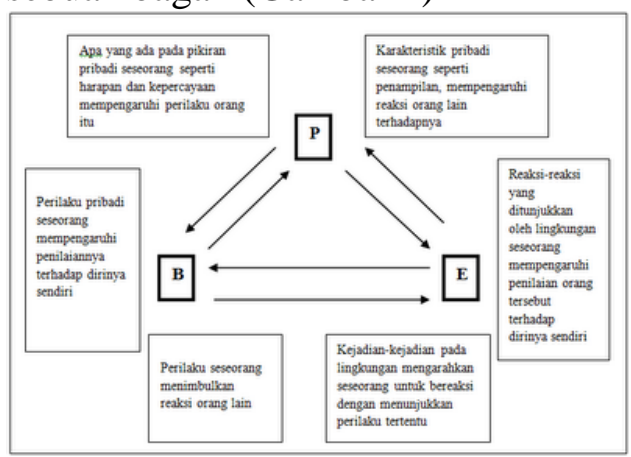

Keterangan :

$\mathrm{P}=$ Singkatan dari Personal atau

Kepribadian Seseorang.

$\mathrm{B}=$ Singkatan dari Behavior atau Perilaku Seseorang.

$\mathrm{E}=$ Singkatan dari Environment atau Lingkungan Luar.

Sistem yang saling terkait seperti yang ditampilkan dalam bagan di atas menggambarkan ketiga faktor yaitu: faktor kepribadian (Personal), faktor perilaku (Behavior), dan faktor lingkungan (Environment). Sepasang anak panah yang berlawanan arah pada setiap faktor tersebut menunjukkan bahwa setiap faktor tersebut dapat mempengaruhi atau dapat bersifat sebagai penentu terhadap faktorfaktor lainnya secara timbal balik.

Hasil penelitian ini sekaligus membuktikan bahwa perilaku manusia dalam hal interaksi timbal balik yang berkesinambungan antara kognitif, perilaku, dan pengaruh lingkungan (Rakhmat, 2004: 74). Hasil penelitian ini sekaligus menegaskan teori belajar sosial dari Bandura yang menyatakan bahwa individu akan meniru perilaku orang lain jika situasinya sama dengan ketika peristiwa yang ditirunya diperkuat di masa lalu. Hasil penelitian menunjukkan bahwa remaja menirukan perilaku temantemannya, , peniruan ini akan diperkuat dengan persetujuan teman sebayanya. Bahkan Teori Belajar Sosial Bandura juga dapat digunakan untuk memperkuat bahwa pendengar dimana kebanyakan adalah usia remaja menirukan perilaku awak media radio Prambors yang dimana dianggap adalah teman mereka. Dimana jika awak media Prambors termasuk penyiar menyatakan sikap anti kekerasannya , tentu pendengar akan setuju dan mendukung perilaku mereka.

Seperti yang sudah dikatakan di atas, penelitian ini menggunakan teori belajar sosial dari Bandura. Menurut teori ini, yang dipelajari individu terutama dalam belajar sosial dan moral terjadi melalui peniruan (imitation) dan penyajian contoh perilaku (modeling). Teori ini juga memandang pentingnya conditioning. Melalui pemberian reward dan punishment, seorang individu akan berfikir dan memutuskan perilaku sosial mana yang perlu dilakukan.Dengan melihat hasil bahwa terdapat hubungan positif antara terpaan iklan dan interaksi peer group dengan sikap anti kekersan remaja maka dapat dikatakan bahwa hasil penelitian ini memberi dukungan atas teori belajar sosial Bandura tersebut. Bahkan dapat dikatakan bahwa hasil penelitian ini merupakan bukti empirik 
adanya terpaan media massa disini adalah radio terhadap sikap pendengar.

\section{Penutup}

Dampak yang ditimbulkan dari penelitian ini adalah dimana media massa sebagai ruang untuk menyampaikan pesan positif seperti yang dilakukan oleh Radio Prambors di Kota Semarang yang mengangkat tema mengenai isu-isu sosial terkini dimana salah satunya adalah yang merajalela di kalangan masyarakat Indonesia yaitu isu mengenai kekerasan. Media massa memiliki kekuatan strategis dalam menyebarkan informasi,sehingga memiliki pengaruh dalam membentuk sikap dan norma sosial suatu masyarakat. Media massa juga bisa menampilkan teladan budaya yang bijak untuk mengubah masyarakat, sehingga masyarakat dapat dipengaruhi oleh terpaan media massa (Reza et al., 2012).

Radio Prambors sesuai visinya ingin mengajak kawula muda yang notabene adalah anak-anak remaja untuk memerangi kekerasan dan berbuat lebih positif salah satunya melalui musik dimana Radio Prambors adalajh salah satu radio anak muda yang menjadi media hobi positif remaja masa kini yaitu berupa audio. Sehingga diharapkan Pendengar Radio Prambors dengan sebutannya kawula muda terhindar dari segala bentuk aktivitas yang berkaitan dengan kekerasan dan lebih memilih segala bentuk kegiatan yang positif dengan salah satunya mendengarkan musik. Ide mengangkat isu sosial mengenai kekerasan melalui pesan iklan anti kekerasan yang diusung oleh Radio Prambors memiliki dampak positif terhadap sikap anti kekerasan remaja, sehingga dapat memotivasi dan mempersuasi kawula muda untuk setuju menghindari kekerasan dan melakukan hal yang positif seperti yang dikatakan dalam teori belajar sosial milik banfuta yangmengatakan bahwa hal yang dipelajari individu terutama dalam belajar sosial dan moral terjadi melalui peniruan (imitation) dan penyajian contoh perilaku (modeling). Hadirnya pesan iklan anti kekerasan menjadikan hal yang positif dalam menyebarkan semangat positif ke masyarakat luas melalui kawula muda yang mendengarkan dan terterpa pesan iklan tersebut.

Rekomendasi untuk penelitian selanjutnya adalah bahwa peneliti berikutnya diharapkan dapat memepertajam penelitian selanjutnya menggunakan metode campuran (mix method) yang menggabungkan metode survei dan metode wawancara. Metode campuran (mix method) digunakan untuk memperoleh hasil penelitian yang dapat melengkapi apabila hasil penelitian menggunakan metode kuantitatif yaitu survei kepada pendengar setia radio Prambors memerlukan data pendukung dalam menjelaskan tujuan penelitian maka dapat menggunakan metode kualitatif yaitu wawancara pihak terkait dalam penelitian yang melibatkan pihak-pihak yang berwenang.

Bukti bahwa ternyata terpaan iklan memiliki hubungan dengan sikap anti kekerasan remaja, terutama pendengar Radio Prambors, seharusnya membuat manajemen Radio Prambors lebih meningkatkan frekuensi iklan serupa untuk menurunkan anga kekerasan remaja di masyarakat. Kualitas pesan (melalui inovasi keberagaman tema untuk iklan anti kekerasn remaja) juga perlu ditingkatkan agar menimbulkan dampak yang signifikan terhadap sikap remaja terkait dengan kekerasan.

Pemerintah Daerah seharusnya mendukung dan memfasilitasi stasun radio Prambors dalam menyebarkan kegiatankegiatan termasuk pesan iklan yang mendorong gerakan anti kekerasan. Karena hal ini terbukti memiliki hubungan yang signifikan dengan sikap remaja terhadap kekerasan.

Masyarakat kota Semarang juga diharapkan dapat menggunakan media massa Radio sebagai sarana mendorong 
gerakan anti kekerasan pendengar setia Radio Prambors.

Meskipun berhasil menjawab permasalahan penelitian namun penelitian ini masih memiliki beberapa keterbatasan. Keterbatasan penelitian ini antara lain:

1. Variabel yang diteliti untuk membahas fenomena sikap anti kekerasan remaja dalam penelitian ini hanya dua, yaitu peer group dan terpaan iklan. Dengan melihat angka Adjusted $r$ Square maka nampak bahwa kedua faktor ini masih belum bisa menggambarkan fenomena sikap anti kekerasan remaja. Artinya masih ada faktor lain yang belum dibahas dalam penelitian ini yang memiliki hubungan dengan sikap anti kekerasan remaja.

2. Penelitian ini dilakukan terhadap pendengar setia Radio Prambors yang ada di Semarang. Dengan demikian sebenarnya hasil penelitian bukan merupakan representasi dari seluruh pendengar setia di kota-kota lain di Indonesia. Hal ini mengingat karakteristik remaja masing-masing daerah tentunya berbeda satu dengan yang lain.

\section{Daftar Pustaka}

Belch, G. E., \& Belch, M. A. (2004). Advertising and Promotion: An Integrated Marketing Communications Perspective (Edisi ke-6). New York: Mc Graw-Hill Company.

Effendy, O. U. 2002. Ilmu, Teori dan Filsafat Komunikasi. Bandung: Citra Aditya Bakti.

Horton, R. L. (1984). Buying Behavior a Decision Making Approach. Ohio: Charles E Merril Publishing Company.
Hurlock, E. B. (2004). Psikologi Perkembangan: Suatu Pendekatan Sepanjang Rentang Kehidupan. Jakarta: PT. Gelora Aksara Pratama.

Rakhmat, J. (2004). Psikologi Komunikasi. Bandung: PT Remaja Rosdakarya.

Santrock, J. W. (2007). Adolescence: Perkembangan Remaja (Edisi Keenam). Jakarta: Erlangga.

Sugiyono. (2012). Metode Penelitian Kuantitatif, Kualitatif dan $R \& D$. Bandung: Alfabeta.

Well, W., Burnett, J., Moriarty, S. (2003). Advertising Principle and Practice. Prentice Hall.

Bandura, A. (1977). Self-Efficacy: Toward a Unifying Theory of Behavioral Change. Psychological Review, 84 (2), 191-215.

Efianingrum, A. (2006). Wacana Kekerasan dalam Interaksi Remaja Kasus Perkelahian Pelajar di Yogyakarta. Jurnal Humaniora.

Reza, F. P., Sugiana, D., Karimah, K. E. (2012). Hubungan Terpaan Artikel Surat Kabar Seputar Indonesia Tentang Mencontek Skripsi Bisa Dipenjara yang Ada Di Perpustakaan Fikom Unpad Kampus Bandung Dengan Sikap Mahasiswa dalam Mengerjakan Skripsi. E-Jurnal Mahasiswa Univ. Padjajaran, 1 (1).

Sundari. (2014). Dalam Survei, Media Pengaruhi Pilihan Politik. http://www.tempo.co/read/news/201 4/01/14/269544683/dalam-surveimedia-pengaruhi-pilihan-politik. (diakses 14 Juli 2015, pukul 02.13). 